certified seed potatoes should mean the same regardless where produced or sold. If for sufficient reason potatoes in some state or states cannot be produced to comply with the accepted universal standard for certified seed they should be sold under another term, or perhaps as certified seed with modifications stated clearly on the certification tags. The former would be better.

\title{
NEW YORK CO-OPERATIVE SEED POTATO ASS'N, Inc.
}

Members of this organization voted recently to take out active memberships for each of its members in the Potato Association of America. Last year they held associate memberships. This step denotes progress and wisdom on the part of the members of the New York Co-operative Seed Potato Ass'n., Inc. It shows that they believe in the true and old maxims- "Seek and ye shall find. Knock and it shall be opened unto you." In the present day potato phraseology we would say-Aim and work to be a better potato grower and you shall be one. But just manual labor alone will not make a better potato producer, knowledge of growing and marketing the crop is fundamental.

\section{DIE KARTOFFEL}

The above words translated into English means- "The Potato." It is the name of the publication published semi-monthly by the Potato Growers Association of Germany. According to Die Kartoffel, Vol. 6, No. 3. Feb. 1, 1926, this association has a membership of 3982. Can United States and Canada do as well as Germany? If we cannot we had better devote our efforts to other things.

\section{THE USE OF GOOD SEED POTATOES BY WASHINGTON GROWERS}

\section{George L. Zundel, Extension Plant Pathologist}

The last year or two I have furnished your magazine with a number of articles showing the value of the use of good seed that is free from the virus diseases as compared with the common seed that is apt to be more or less badly infected with mosaic and related troubles.

Each year evidence in favor of good seed mounts rapidly and it it surprising to know that even in this enlightened day we still have farmers who think they cannot afford to pay a good price for high grade certified seed. The argument of some of these men put forward that results are only for one year is gradually becoming invalid since we now have results on the control of mosaic for at least five years. 